\title{
Availability of olfactory bulb: experience from a British Brain Bank
}

\author{
Disponibilidade de bulbos olfatórios em um banco de cérebro britânico: a experiência do \\ Queen Square Brain Bank
}

Suraj Rajan', Linda Parsons², Andrew J Lees³, Laura Silveira-Moriyama4

\begin{abstract}
The olfactory bulb and tract (OB/OT) are among the earliest structures in the brain to undergo pathological changes in many neurodegenerative conditions. The availability of OB/OT samples from brain specimens in brain banks therefore assumes importance. We collected data from 5 years (2006-2010) regarding the presence or absence of OB/OT material in cases received by the Queen Square Brain Bank (QSBB) for Neurological Disorders, UCL Institute of Neurology, UK, to estimate availability of OB/OT material at the brain bank and also to look for possible associations. Of the 438 cases received, 320 had complete data regarding OB/OT and $29.4 \%$ of these had OB/OT in at least one half of the specimen. Unavailability of OB/OT was associated with larger post-mortem delays $(p<0.001)$, suggesting that the delay might render the tissue more friable and hence lead to its loss. Brains from female donors also tended to have a higher availability in our samples.
\end{abstract}

Key words: olfactory bulb, olfactory tract, brain bank, autopsy, Parkinson's disease.

\section{RESUMO}

O bulbo e o trato olfatórios (OB/OT) são algumas das estruturas cerebrais mais sensíveis a neurodegeneração. A disponibilidade deste material para estudos neuropatológicos em bancos de cérebro tem, portanto, grande relevância. Coletamos dados referentes a 5 anos (2006-2010) a respeito da presença ou ausência de OB/OT no Queen Square Brain Bank (QSBB) for Neurological Disorders, parte do UCL Institute of Neurology, Reino Unido, para estimar a disponibildade deste material em um banco de cérebro, e também para estudar fatores que influenciam essa disponibilidade. Dos 438 casos recebidos, encontramos dados referentes a presença ou ausência de OB/OT em 320, dos quais 29,4\% possuiam OB/OT em pelo menos um lado. A indisponibilidade de OB/OT foi associada a maior intervalo entre a morte e a autópsia(p<0.001), sugerindo que o atraso pode deixar o material mais friável, levando aperda durante a coleta. Cérebros de doadoras femininas apresentaram maior disponibilidade de OB/OT em nossa amostra.

Palavras-Chave: bulbo olfatório, trato olfatório, banco de cérebro, autópsia, doença de Parkinson.

Olfactory deficits are now considered a key symptom of neurodegenerative conditions with a high prevalence in several neurodegenerative diseases. Numerous studies on the pathophysiologic changes in the olfactory bulb and tract (OB/ OT) associated with Parkinson's disease (PD), progressive supranuclear palsy, multiple system atrophy and Alzheimer's disease, among other conditions, support this ${ }^{1}$.
Braak et al., in their seminal paper on the pathological staging of PD had demonstrated that the OB is among the earliest structures in the brain to be affected by Lewy body pathology ${ }^{2}$. Lewy body deposition has been shown to extend to the olfactory cortical areas as well ${ }^{3}$. Histopathological and functional studies of the OB are hence paramount to the understanding of the neurodegenerative process in PD.

${ }^{1}$ MBBS., MSc. UCL Institute of Neurology, London, UK;

${ }^{2}$ MPhil. Queen Square Brain Bank for Neurological Disorders, UCL Institute of Neurology, UK;

${ }^{3}$ MD., FRCP. Queen Square Brain Bank for Neurological Disorders and Reta Lila Weston Institute of Neurological Studies, UCL Institute of Neurology, UK;

${ }^{4} \mathrm{MD}$., PhD Reta Lila Weston Institute of Neurological Studies, UCL Institute of Neurology, UK; Department of Neurology, University of Campinas, UNICAMP, Brazil. Correspondence: Laura Silveira-Moriyama; Reta Lila Weston Institute of Neurological Studies, UCL Institute of Neurology, 1 Wakefield Street, London WC1 N

1PJ, UK; E-mail: laura.moriyama@ucl.ac.uk

Conflict of interest: Suraj Rajan and Linda Parsons: reports no disclosures.

Andrew J Lees: Andrew Lees discloses financial support from the Reta Lila Weston Trust, University College London, Parkinson's UK and PSP Association. He is on the specialist board for Novartis, Teva, Meda, Boehringer Ingelheim, GSK, Ipsen, Lundbeck, Allergan, Orion, BIAL, Noscira, Roche, has received consultancy fees from Genus, and honoraria from Novartis, Teva, Meda, Boehringer Ingelheim, GSK, Ipsen, Lundbeck, Allergan, Orion, BIAL, Noscira and Roche. Laura Silveira-Moriyama: Laura Silveira-Moriyama discloses financial support from the Reta Lila Weston Trust, University College London, University of Campinas, Parkinson's UK and Virginia Keiley Benefaction, and travels grants from UCB, Teva and Boehringer-Ingelheim.

Received 20 August 2012; Received in final form 08 October 2012; Accepted 15 October 2012 
The availability of OB/OT samples from brain specimens in brain banks assumes high importance in this context. The Queen Square Brain Bank for Neurological Disorders, UCL Institute of Neurology, UK (QSBB) holds a collection of brains donated specifically for research into human neurodegenerative diseases and uses a protocol approved by a London Multi-Centre Research Ethics Committee where tissue samples are stored under a full license issued by the Human Tissue Authority.

\section{METHODS}

We collected data regarding the presence or absence of material from the olfactory bulb and tract in cases received by the QSBB between the years of 2006 and 2010 (both years inclusive) to estimate availability of $\mathrm{OB} / \mathrm{OT}$ material at the brain bank. The Queen Square Brain Bank receives post-mortem brain specimens after initial processing by local autopsy services. One half of each brain is randomly assigned to be flash-frozen and the other half, formalin-fixed. Our data is drawn from the pool of formalin-fixed halves.

\section{RESULTS}

A total of 438 cases were received at QSBB over 5 years, and final histopathological diagnoses were as follows: control brain ( $n=21 ; 4.8 \%)$, Lewy body pathology ( $n=121 ; 27.6 \%)$ Tauopathies $(n=112 ; 25.6 \%)$, Alzheimer's disease $(n=62$; $14.2 \%)$, Multiple system atrophy $(n=45 ; 10.3 \%)$, others $(n=77$; $18 \%)$. Of these, $320(73 \%)$ cases had data on availability of OB/OT. The OB/OT was present in at least one of the sides of the brain specimens in 94 cases $(29.4 \%)$. Table shows the comparison between cases which did or did not have OB available for post-mortem examination.

\section{DISCUSSION}

The Queen Square Brain Bank receives post-mortem brain specimens after initial processing by local autopsy services. It is known that the OB/OT can be difficult to harvest because it can get stuck to the skull-base ${ }^{4}$, and other brain banks also have reported unavailability of $\mathrm{OBs}^{5}$. But to our knowledge, ours is the first study to suggest that post-mortem delay could have an impact on the availability of the OB. It is possible that post-mortem decomposition renders the tissue more friable and therefore causes rupture of the olfactory tract when the brain is pulled out of the skull 6 .

We also found that brains from females had a higher availability of OB than males ( $\mathrm{p}<0.035$, see table). The difference is statistically significant even after adjusting for post-mortem delay $(p=0.028)$. However, the pathophysiologic or anatomic basis of this is as yet unclear, as previous studies have not found any difference in $\mathrm{OB}$ anatomy with regard to gender. It is well known that females have better olfaction than males ${ }^{8}$ and therefore the possibility of underlying physiologic factors influencing the tissue characteristics of male and female OB/ OT cannot be ruled out?

For other brain banks which centralise collection from registered donors and are therefore dependant on the speed and technical expertise of the local autopsy services, this information might be relevant. We welcome data regarding the same, from other brain banks, which may help improve protocols for autopsy services around the world to ensure proper retrieval of olfactory structures and thus aid in future neurological research.

1. Table: Availability of olfactory bulb and possible correlates.

\begin{tabular}{|c|c|c|c|}
\hline Correlates & $\begin{array}{l}\text { Olfactory bulb Absent } \\
\qquad(n=226)\end{array}$ & $\begin{array}{l}\text { Olfactory bulb Present } \\
\qquad(n=94)\end{array}$ & Significance $p$-value \\
\hline $\begin{array}{l}\text { Age in years: } \\
\text { mean (SD; range) }\end{array}$ & $73.2(10.1 ; 38-99)$ & $74.6(12.4 ; 24-99)$ & $0.317 *$ \\
\hline $\begin{array}{l}\text { Gender: } \\
\text { Number of females (\%) }\end{array}$ & $82(36.3 \%)$ & $46(48.9 \%)$ & $\begin{array}{c}\chi^{2} p \text { value }=0.035 ; \text { P value adjusted for age } \\
(p=0.51) \text { and post-mortem delay }(p<0.001) \\
\text { by logistic regression }=0.028\end{array}$ \\
\hline $\begin{array}{l}\text { Post-mortem delay } \\
\text { in hours: } \\
\text { mean (SD; range) }\end{array}$ & $\begin{array}{c}63.4 \\
(S D=28 \\
4.5-123.5)\end{array}$ & $\begin{array}{c}50.5 \\
(S D=27.5 \\
3.0-141.8)\end{array}$ & $<0.001 *$ \\
\hline
\end{tabular}

SD: standard deviation; *Student’s t test

\section{References}

1. Duda, JE, Olfactory system pathology as a model of Lewy neurodegenerative disease. J Neurol Sci 2010;289:49-54.

2. Braak H, Del Tredici K, Rueb U, et al. Staging of brain pathology related to sporadic Parkinson's disease. Neurobiol Aging 2003;24:197-211.
3. Silveira-Moriyama L, Holton JL, Kingsbury A, et al. Regional differences in the severity of Lewy body pathology across the olfactory cortex. Neurosci Lett 2009;453:77-80.

4. Pearce R, Hawkes C, Daniel S. The anterior olfactory nucleus in Parkinson's disease. Mov Disord 1995;10:283-287. 
van den Berge SA, van Strien ME, Korecka JA, et al., The proliferative capacity of the subventricular zone is maintained in the parkinsonian brain. Brain 2011;134:3249-3263.

6. Ravid R, Van Zwieten EJ, Saab DF. Brain banking and the human hypothalamus--factors to match for, pitfalls and potentials. Prog Brain Res 1992;93:83-95.
7. ul Haq S, Tahir M, Lone KP. Age and gender-related differences in mitral cells of olfactory bulb. J Coll Physicians Surg Pak 2008;18: 669-673.

8. Doty, RL, Bromley SM \& Stern MB 1995. Olfactory testing as an aid in the diagnosis of Parkinson's disease: development of optimal discrimination criteria. Neurodegeneration,1995;4: 93-97. 